TEXT Vol 11 No 1 (April 2007)

\title{
Poetry contents
}

- Kevin Brophy, How to read a poem page 2

- Joel Deane, reading. About page 4

- Stephen Lawrence, Something needs my attention page 5 


\section{Kevin Brophy}

\section{How to read a poem}

Is too modest and private an aim when you could learn How to build a home inside a poem or How to talk a poem into introducing you to her family.

You might instead of merely reading a poem wish to learn How to bake a poem for months, then take it from its oven without burning one finger on it. How to resist a poem is a hardback volume invaluable to lovers, soldiers and lachrymose critics. How to misread a poem is a necessary read for the salvation of your own poetry, as is How to make a poem tell the truth and How to be smarter than a poem.

For those who understand the social occasion of the spoken word, How to take a poem out to lunch can become an expensive pleasure and a puzzle for the lips. The book and video, How to workout with a poem, comes with Rilke's Panther Brand leotards and promises eloquent beginnings to new relationships. You will be relieved to find still in print, How to put a poem back on the shelf, And that How to get a refund from a faulty poem requires a standard form unavailable anywhere. How to replace the batteries in a poem should not take more than a minute to understand.

Kevin Brophy's new collection of poetry, Mr Wittgenstein's Lion will be published in June 2007 by Five Islands Press. Kevin Brophy is an associate professor lecturing in creative writing in the School of Culture and Communication at the University of Melbourne. 


\section{TEXT}

Vol 11 No 1 April 2007

http://www.griffith.edu.au/school/art/text/

Editors: Nigel Krauth \& Jen Webb

Text@griffith.edu.au 


\title{
Joel Deane
}

\section{reading. About}

\author{
About \\ reading. About \\ thinking about what I am reading. About \\ talking about what I am reading. About \\ thinking about what other people are saying about what they are reading. About \\ talking about what other people are thinking about what they are reading. \\ About \\ reading about what other people are writing about what they are thinking and \\ saying about \\ what they are reading. About \\ writing about what I think and say about and other people say and think about \\ reading. \\ what I and they and they and I are reading. About
}

Joel Deane is the senior speechwriter for the Premier of Victoria, Steve Bracks. His first collection of poetry, Subterranean Radio Songs (Interactive Press, 2005), was shortlisted for the Anne Elder Award. He has also published a novel, Another (IP, 2004).

\section{TEXT}

Vol 11 No 1 April 2007

http://www.griffith.edu.au/school/art/text/

Editors: Nigel Krauth \& Jen Webb

Text@griffith.edu.au 


\section{Stephen Lawrence}

\section{Something needs my attention}

A delirium of repetition, infraverbal, climbs to threshold, tumbles me out of bed. What could make my body tug itself reluctantly from under this bed's quilt, plan a slanting path to the laundry the hard-tiled night laundry, of all places? An outlandish combination of chemicals in one warm pool, urges its filtrate to rescue this thought from oblivion; its tiny influence squirts a wisp of extra serum sets off a memory-relay, a race to a poem. I slap to this shadowed room, finger-greet a clothes-hook, an ironing board; I negotiate a cupboard door's substance, spine it back into position. A pencil breathes invisible words across its mat, this poem fixes to the page, an elbow nudges aside heaped washing. Its tilting pile's moon-grey outline fresh-kill warmth leached into space resolved to ashen thermalwear, socks, briefs, waiting to find their wardrobe resting places; Before I rejoin my sleeping self... What else? A reminder from the spinal brain: Go piss.

Stephen Lawrence works for the State government, and has taught literature and writing skills at schools and universities. He is a poetry editor for Wet Ink, and was guest poetry editor for Social Alternatives. His third collection, How Not to Kill Government Leaders, was launched at Writers' Week (Adelaide) 2002, and he was a judge for the Festival of Arts Literary Awards in 2002 and 2006. He is currently enrolled in a Creative Writing PhD at the University of Adelaide. 


\section{TEXT}

Vol 11 No 1 April 2007

http://www.griffith.edu.au/school/art/text/

Editors: Nigel Krauth \& Jen Webb

Text@griffith.edu.au 